\title{
Specifications and types of seawall structures needed to protect beaches from sand erosion and storm disasters
}

\author{
Khosro Zehro \\ Faculty of Civil and Environmental Engineering, Near East University, Nicosia, Mersin10, Turkey
}

\section{A R T ICLE INFO}

ARTICLE HISTORY:

Received: 10 June 2020

Revised: 04 July 2020

Accepted: 27 July 2020

Published: 27 July 2020

\section{KEYWORDS:}

Seawall, coastal, erosion, shoreline, shore protection

\section{A B S T R AC T}

\section{INTRODUCTION}

By potential risks from storms and other environmental disasters, coastlines have gradually transformed, materials eroding and moving from certain areas to others (Luo, 2014). The storms are; hurricanes, tropical storms, typhoons, tornadoes, winter storms, and cyclones, resulting in casualties, their investment loss, and coastal environment hazards. The lower sedimentary shores have lesser flooding resistance (Liu et al., 2019).

Temperature change, rising sea levels, and patterns of rainfall are results of the natural climate cycle. Consequently, rising sea levels and both the average level of water and wave height will increase during the utmost weather conditions. This process induces erosion of soils from shores resulting in beach intrusion and the impact on human activities (Jin et al., 2015).

Anything built on the shoreline is known as coastal structures and constructed explicitly to the protection of the shoreline. This kind of structural system is designed to withstand waves, scouring, and beach erosion. Coastal designs were considered recently, such as a barrier between shore and sea, a global issue. Over decades to stop the rate of erosion, coastal defence implemented a fence (commonly seawalls) formed a critical requirement (Church et al., 2013).

A structural treatment such as groins, seawalls, embankments, jetties, and levees has been a conventional coastal disaster prevention mechanism, especially preferred in the expansion of urban concentration near seas, between much different sustainable developments, widely considered (Davlasheridze \& Fan, 2019). Nearly 60 per cent of the population is resident in coastal regions, and about 100 kilometres in the coastline (Perkol et al., 2018).

Seawalls include self-supporting structures relating to the prevention of flooding or coastline retreats, and constructed mostly on coasts parallel to the coastline and usually prepared of reinforced concrete to overcome 
sliding or moments by overturning. The necessary design part is the elevation of the crest, becoming over-topping of waves and run-up of the waves.

Erosion was a natural coastal process that can be short-term, long-term or periodic that is caused by factors as rises of sea level, losses of supplied sediments, wave behaviour changes. Fortunately, there are other strategies in coastal engineering that support or avoid continued shorelines erosion which classified in various ways, according to Kraus (1988) study such as:

- Hard stabilizations; include some enduring rigid structures by a fixed position, like as; groins, seawalls, and suspended breakwaters,

- Soft stabilizations; refilling of the shores,

- Retreats and relocations; peoples transferred from near beaches to other locations to allow the process of natural recovery for the coast.

The seawalls construction has many limitations, which can be related to climate and conditions of the sea like the significant height of the wave, the average speed of the wind, and continually heavy rainfall (Yoo et al., 2013). By considering different techniques, it proved that the rubblemound type of seawalls construction is the cheaper type than others, which with ordinary workers, could construct it without using any machine. One more positive aspect is the extension of construction year after year, regarding funding availability (Manu et al., 2015).

The main objective of this study is to identify the four types of seawall structures and their importance in protecting beaches from erosion that necessary for people's infrastructure investment safety assurance results from disasters near the coasts. Moreover, it explains the factors affecting the sustainability of these structures and preventing them from failure probabilities.

\section{METHODOLOGY}

The study's information was collected by the literature review of the recent coastal researches, and their investigation about climate conditions, erosion, design of seawall structures, and stability needed for structures.

\section{COASTAL STRUCTURES}

Shore structures used in the shore protection plans with the purpose of protecting beach erosion and hinterland flooding. Other purpose includes protecting basins and entrances of harbours from waves, stabilizing inlet channels, and protecting water outfalls and intakes (Burcharth \& Hughes, 2003). Table 1 explains the different kinds of shore structures and their functions.
Table 1. Some common types of coastal structures and their functions

\begin{tabular}{|l|l|}
\hline \multicolumn{1}{|c|}{$\begin{array}{c}\text { Kind of } \\
\text { structure }\end{array}$} & \multicolumn{1}{c|}{ Aims and functions } \\
\hline Seawall & $\begin{array}{l}\text { Protection of structures and land from } \\
\text { Overtopping and flooding. Reinforcing of } \\
\text { certain areas of the shore profile }\end{array}$ \\
\hline Breakwater & $\begin{array}{l}\text { Sheltering harbours entrances and basins, } \\
\text { and intakes of water from waves. } \\
\text { Dissipation the energy of wave and wave } \\
\text { reflections back to the sea }\end{array}$ \\
\hline Groin & $\begin{array}{l}\text { Protecting shore erosion. Reducing long- } \\
\text { shore transportation of sediments. }\end{array}$ \\
\hline Jetty & $\begin{array}{l}\text { Stabilizing channels at river entrances and } \\
\text { inlets. Protecting storms disaster. }\end{array}$ \\
\hline Revetment & $\begin{array}{l}\text { Protection of coasts from erosion. } \\
\text { Reinforcing certain part of shore profile }\end{array}$ \\
\hline Sea dike & $\begin{array}{l}\text { Prevent sea flooding energy from low-lying } \\
\text { shore areas. Separating coastline from } \\
\text { hinterland by structures with high } \\
\text { impermeability. }\end{array}$ \\
\hline Bulkhead & $\begin{array}{l}\text { Maintain soil and preventing of behind soil } \\
\text { sliding. Reinforcing the bank of the soil. }\end{array}$ \\
\hline $\begin{array}{l}\text { Nourishment of } \\
\text { beaches and } \\
\text { construction of } \\
\text { duns }\end{array}$ & $\begin{array}{l}\text { Preventing shore erosion and protection } \\
\text { from flooding. Artificial infill of shores and } \\
\text { dune materials that eroded with waves in } \\
\text { place of natural supplies. }\end{array}$ \\
\hline
\end{tabular}

\section{SEAWALLS}

Seawalls are usually coastal structures, which are adjacent to the seashores. The fundamental roles of these structures are, to inhibit marine areas erosion from flooding and prevention of the constructed building structures near the shore. To create seawall structures, different materials are used, including concrete, gabion, cribs filled by stone, casting concrete in the site, precast blocks, and prefabricated segments. The seawalls types can be constructed in the vertical, curved, rubblemound, or stepped surface. In certain situations, large structure by suitable foundations and practical toe support needed to overcome and control the damage of significant wave effects (Sadeghi \& Al-Othman, 2019).

Sea walls become factors of their-self demolition if they not properly construct. The sea waves will crush versus it, while decline its front face, strive to remove the shore soil in its base, transferring of these soils, if not kept down, forces the wall to be undermined and collapse. Sea walls not constructed to decrease soil sedimentation only, but they protect industrial factories, bridges, railways, and roads from attacking by waves and storms. As also resist flooding damage on low lying areas (Williams et al., 2016).

Sea wall installed in the coastline at a specific location that changes the hydrodynamic status by interacting with repetitive sea waves. By controlling soil erosion from cutting off sea walls, typical sediments supplied when 
waves which impact sea wall reversed down, scouring the wall's toe as an outcome (Pilkey \& Cooper, 2012).

Sea walls construct to reduce the wave's power and soil erosion that already exposed shorelines. The appropriate design for the sea wall and its types depends on locationspecific features such as erosion processes around it (Balaji et al., 2017).

\section{TYPES OF SEAWALLS}

The different details or types of the seawall are used to construct along with the coastline structures such as vertical, curved, rubble mound and stepped seawall. Others include the gravity, seawalls made by concrete blocks, and the piles made by sheets of steel.

\subsection{Vertical seawall}

Vertical-face sea walls generally consist of materials like blocks of stone, mass concrete, and $\mathrm{RC}$, and it can construct as interlock walls by using concrete, wood piling, and steel. Another form of the vertical wall can install using rock-filled as a sizeable concrete wall that behaves like retaining walls against materials behind them (Balaji et al., 2017).

Vertical face sea walls often constructed in situations that are subjected to such wave power. Non-breaking static waves arise during flood effects where it rolls upward and downward not horizontally. This wave promoting can cause serious risk to the seawall in the wall toe. Fig.1 shows the detail of vertical face seawall (Williams et al., 2016).

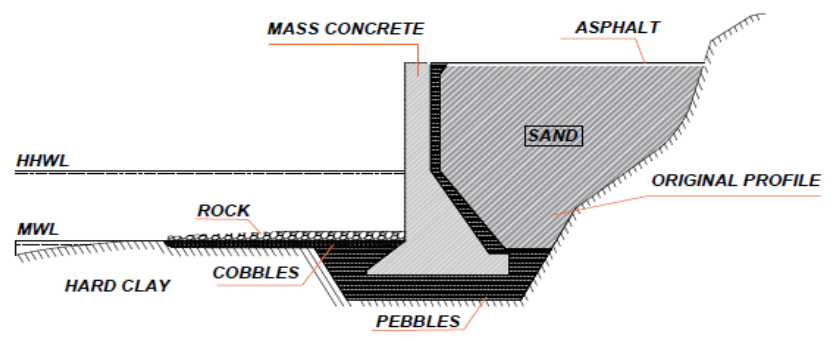

Fig. 1. Vertical front seawall

\subsection{Curved face seawall}

The curve face model will prevent walls from wave overtopping and protect walls' toes effectively. Curved face sea walls attempt to redirect all the risky wave power, results from reflected energy of waves and considerably reduced downdrafts (Vijayaraghavan et al., 2018). Curved types seawall constructed to protect the impact of the intense action of waves. By using piles' sheet cut off seawalls can prevent the loss of materials in the foundation around, resulted in waves' scouring, eroding from water overtopping, and floods drain below the wall (see Fig. 2). Additionally, to reduce waves' scouring, the toe section of the curve face wall is constructed by big stones (Sadeghi et al., 2018).

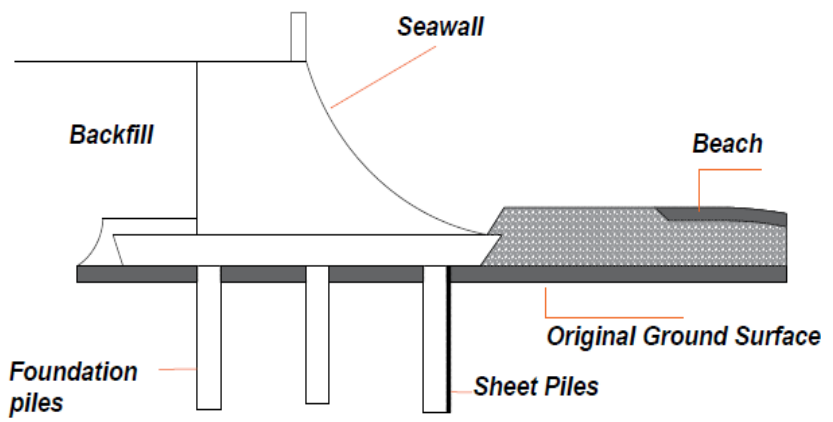

Fig. 2. Seawall with curved face configuration

\subsection{Stepped face seawall}

Stepped types of the seawall are designed to resist and reject moderate action of waves. Reinforcing concrete sheet pile used in the construction of these kinds of seawalls (see Fig. 3). The areas that built between sheet piles are mostly filled by grouts to maintain sand cut off or installation of geotextile fibres at the sheet piles' back, to generate a sand-tightened barrier. Installing geotextile is helpful since it facilitates water flowing through and thus prevents the development of hydrostatic pressures (Sadeghi et al., 2018).

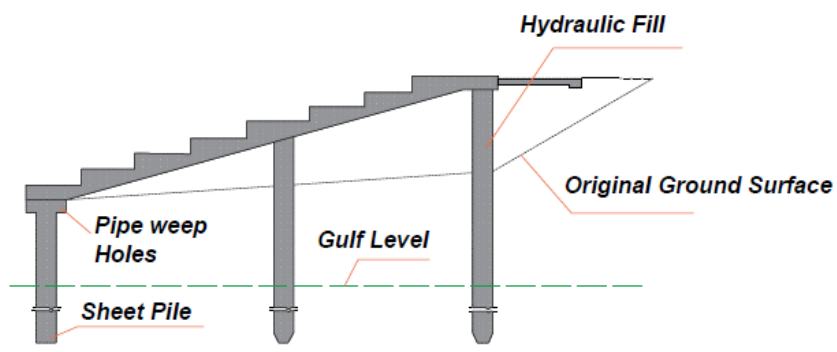

Fig. 3. Stepped face seawall

\subsection{Rubble-mound seawall}

These kinds of seawalls were cheaper and easier for construction and designing and could protect the energetic action of waves substantially (see Fig. 4.).

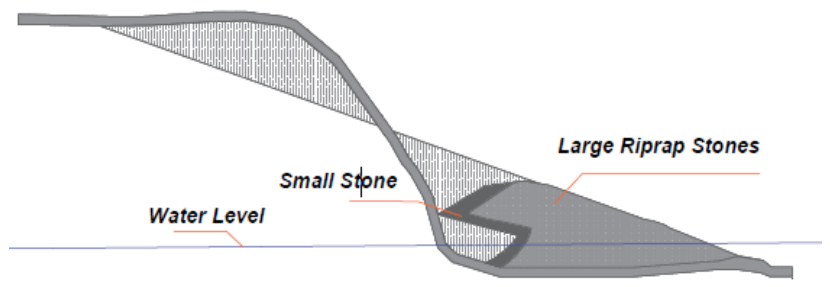

Fig. 4. Rubble-mound seawall 
Mound form of seawalls built by using rip rap or revetments, and usually in less requiring applications used, where erosion process with low energy occurs. The least rate of exposure means the lower bulkheads' cost and revetments' sandbag. These are serving to shores' armour and reduce erosion, also can either be waterproof or porous form, allow the filtering of water after the dissipation of the waves' power (Vijayaraghavan et al., 2018).

\section{FACTORS AFFECTING FAILURE IN SEAWALLS}

According to Wang et al. (2012) and the site investigators, the damaged mechanism of seawalls' failure can be divided into two kinds: the collapse of the introversion, and dispersion collapse. The sea walls structures failure is strongly related to mortar hydrodynamic effects and invalidation. Different types of geotechnical or structural occurrences of failures are as following:

- Hydraulic uncertainty (primary armour depletion),

- Overtopping leads to scouring of seawalls' crest,

- Scour or erosion at the toe,

- Liquefaction (action of waves decreases sand bearing capacity, allowing the armour to submerge),

- Inside erosion (material losses of inside the wall),

- Central instability, it is unusual for rock wall builds.

Some types of common failures reported by surveying in the UK with coastal authorities shown in Table 2 (Thomas \& Hall, 2015).

Table 2. Different kinds of damages

\begin{tabular}{|l|c|}
\hline \multicolumn{1}{|c|}{ Seawall damages } & $\begin{array}{c}\text { No. of } \\
\text { occurrences }\end{array}$ \\
\hline Collapse & 16 \\
\hline Disintegration of concrete & 9 \\
\hline Armouring uplift & 3 \\
\hline Armour removal in revetments & 19 \\
\hline Erosion in toe & 63 \\
\hline Abrasion & 16 \\
\hline Wash-out filled materials behind seawalls & 10 \\
\hline Cracking in concrete & 2 \\
\hline Settlement & 2 \\
\hline Promenades damage & 4 \\
\hline Corrosion & 3 \\
\hline Partial failure in crest & 26 \\
\hline Outflanking & 3 \\
\hline Concrete spalling & 2 \\
\hline Failure in structural members & 5 \\
\hline Landslip & 5 \\
\hline Total & 188 \\
\hline
\end{tabular}

Increasing seawalls exposure with a rising water level during time is going to affect the overtopping, hydraulic stabilization, and toe scouring as the sea wall experienced. In the study by Mulcahy et al. (2017), it explained that changing climate could also directly impact the vulnerability of seawalls by:

- Rising seas' level,

- Increasing storms surge,

- Increase in the height of waves,

- Unpredictable geo-morphological impacts due to climate change.

\section{STABILITY OF SEAWALLS}

Based on various factors like sea walls weight, the different applied force upon seawalls, as well as the resistance of foundation soil and back-fill materials, the rotation of seawalls could be toward shore or the seaside. The seawall's stability verified by implementing the equilibrium limit method regards the safety factor against sliding toward shores or overturning toward shore's failure modes. Based on the moving relationship between the water in pores and particles of soil, two conditions considered, i.e., the first one is free-water, and the second is the water that restrained (Rajesh \& Choudhury, 2016).

There are a lot of strategies that could be placed in a way to enhance seawall's ability. Some alternatives outlined by the "climate change adaptation guidelines in coastal management and planning" (Engineers Australia, 2012). That including (but does not restrict to):

- Retreat or permit occurrence of erosion,

- Exposure reduction by raising the volume of the upper shore,

- Develop further layer of bigger armour unit in front of seawalls, to enhance the armour unit stability,

- Placement of further stones on the crest, expanding the width, and raising the height of the crest leads to minimizing the damage of overtopping,

- Use the best practical design and integrate elements that will enable to maintenance in the future (Tomlinson et al., 2016).

\section{POSITIVE AND NEGATIVE EFFECTS OF SEAWALLS ON COASTS}

While coastal areas undergo erosion deterioration, for controlling the effects of shore losses and damage of storms, using different strategies. Measures of Soft stabilizing involve coast and re-nourishment of the dune, which tend to remain as temporary, however significantly expensive. Measures of hard maintaining like as; seawalls, groins, and jetties effectively prevent coast properties deteriorate. However, they have some negative effects on beaches, as explained in Table 3 (Beatley et al., 2002; Rizkalla \& Savage, 2011). 
Table 3. Advantages and disadvantages of hard stabilization structures to coasts

\begin{tabular}{|l|l|}
\hline \multicolumn{1}{|c|}{ Advantages } & \multicolumn{1}{c|}{ Disadvantages } \\
\hline $\begin{array}{l}\text { Inhibit marine areas erosion } \\
\text { from flooding }\end{array}$ & $\begin{array}{l}\text { Seawalls restrict access to } \\
\text { seawater }\end{array}$ \\
\hline Prevent losses of the beaches & Seawalls become unattractive \\
\hline $\begin{array}{l}\text { Seawalls protect sand } \\
\text { interchange between the coast } \\
\text { and dune, which attempts to } \\
\text { disperse the energy of waves } \\
\text { by storms }\end{array}$ & $\begin{array}{l}\text { Seawalls generate a false } \\
\text { security sense in unsafe areas } \\
\text { and increase high-density } \\
\text { construction development }\end{array}$ \\
\hline $\begin{array}{l}\text { Prevention of the constructed } \\
\text { structures near the shore }\end{array}$ & $\begin{array}{l}\text { Seawalls cause amusement } \\
\text { beaches degradation }\end{array}$ \\
\hline $\begin{array}{l}\text { As also resist flooding damage } \\
\text { on low lying areas }\end{array}$ & $\begin{array}{l}\text { Seawalls almost always cause } \\
\text { rubble and make swimming } \\
\text { risky }\end{array}$ \\
\hline $\begin{array}{l}\text { Seawalls behaves like re- } \\
\text { taining walls against materials } \\
\text { behind them }\end{array}$ & $\begin{array}{l}\text { Seawalls mainly benefit } \\
\text { landowners only }\end{array}$ \\
\hline
\end{tabular}

\section{CONCLUSIONS}

By inducing changes in natural weathering, expected to increase the disaster's repetition and potentially cause enormous human and financial losses. Almost all investigators and decision-makers are incredibly interested in developments related to different alternatives for coastal modification, such as the development of protection structures. This alternative was a conventional method of adapting to locations in which precious resources will be in damage. Besides that, no empirical study about how the public perceives these protection structures.

Seawalls are the most common marine structures, and their construction depends on the sea's natural conditions more than shore effects. Working on the construction of seawalls during extreme sea conditions will result in a reduction in work performance, construction quality, and safety of workers and construction equipment. The seawall's fundamental role is to act as a kind of protection structure to prohibit the erosion of the coasts. Based on the conditions of the site, various seawall types can be constructed to attain this objective. Due to the diverse relationships between natural erosion and coastline nutrition, it may receive incorrect data in measuring erosion in the coastal area.

In brief, the studies aided in highlighting and identifying the conditions of the common seawalls and confirming that creating proper walls do not need to extra reconstruction. Sea walls help to improve the infrastructure of the community's safety against extreme erosion by storms. The study revealed that standard designs for the seawall structures were aligned with the performance of the structure's requirements.

\section{CONFLICT OF INTEREST STATEMENT}

The author declares that there is no conflict of interest.

\section{REFERENCES}

[1] Australia, E. (2012). Climate change adaptation guidelines in coastal management and planning (1st Ed.). Engineers Media, Australia.

[2] Balaji, R., Sathish Kumar, S., \& Misra, A. (2017). Understanding the effects of seawall construction using a combination of analytical modeling and remote sensing techniques: A case study of Fansa, Gujarat, India. The International Journal of Ocean and Climate Systems, 8(3), 153-160. https://doi.org/10.1177/1759313117712180

[3] Beatley, T., Brower, D., \& Schwab, A. K. (2002). An introduction to coastal zone management (2nd Ed.). Island Press.

[4] Burcharth, H. F., \& A. Hughes, S. (2003). Types and Functions of Coastal Structures. In Coastal Engineering Manual (Vol. 6, pp. VI-2-i - VI-2-44). Coastal Engineering Research Center.

[5] Church, J. A., Clark, P. U., Cazenave, A., Gregory, J. M., Jevrejeva, S., Levermann, A., \& Payne, A. J. (2013). Sea level change, PM Cambridge University Press.

[6] Davlasheridze, M., \& Fan, Q. (2019). Valuing seawall protection in the wake of Hurricane Ike. Economics of disasters and climate change, 3(3), 257-279. https://doi.org/10.1007/s41885-019-00045-z

[7] Jin, D., Hoagland, P., Au, D. K., \& Qiu, J. (2015). Shoreline change, seawalls, and coastal property values. Ocean and coastal management, 114, 185193.

https://doi.org/10.1016/j.ocecoaman.2015.06.025

[8] Kraus, N. C. (1988). The effects of seawalls on the beach: an extensive literature review. Journal of Coastal Research, 2(4), 1-28.

[9] Liu, X., Wang, Y., Costanza, R., Kubiszewski, I., Xu, N., Yuan, M., \& Geng, R. (2019). The value of China's coastal wetlands and seawalls for storm protection. Ecosystem services, 36, 100905. https://doi.org/10.1016/j.ecoser.2019.100905

[10] Luo, E. C. R. (2014). Formation of beach profile with the design criteria of seawalls. Civil Engineering and Architecture, 22(1), 24-32.

http://doi.org/10.13189/cea.2014.020103

[11] Manu Kumar C. K., Neeraja, D, K. M., \& Vishwanath, (2015). Design and Analysis of Seawall. International Journal of Engineering Research \& Technology, 4(4), 1402-1406. http://doi.org/10.17577/IJERTV4IS041312

[12] Mulcahy, M. G., Jackson, L. A., \& Corbett, B. B. (2017). Rock seawall design and construction with 
deeper toes for climate change. Australasian Coasts \& Ports 2017: Working with Nature, 820.

[13] Perkol-Finkel, S., Hadary, T., Rella, A., Shirazi, R., \& Sella, I. (2018). Seascape architecture-incorporating ecological considerations in the design of coastal and marine infrastructure. Environmental Engineering, 120, 645-654. https://doi.org/10.1016/j.ecoleng.2017.06.051

[14] Pilkey, O. H., \& Wright III, H. L. (1988). Seawalls versus beaches. Journal of Coastal Research, Special issue No. 4, 41-64.

[15] Rajesh, B. G., \& Choudhury, D. (2016). Influence of non-breaking wave force on seismic stability of seawall for the passive condition. Ocean Engineering, $114,47-57$. https://doi.org/10.1016/j.oceaneng.2016.01.006

[15] Rizkalla, C. E., \& Savage, A. (2011). Impact of seawalls on loggerhead sea turtle (Caretta caretta) nesting and hatching success. Journal of Coastal Research, 27(1), 166-173. https://doi.org/10.2112/JCOASTRES-D-10-00081.1

[16] Sadeghi, K., Abdullahi, I. S., \& Albab, H. F. (2018). Classification of seawalls and their failure: an overview. Academic Research International, 9(1), 1314

[17] Sadeghi, K., \& Al-Othman, D. (2019). An introduction to onshore structures' construction. Academic Research International, 10(1), 1-12.

[18] Thomas, R. S., \& Hall, B. (2015). Seawall design. Butterworth-Heinemann.

[19] Tomlinson, R. B., Jackson, A. L., \& Bowra, K. (2016). Gold Coast Seawall: Status Investigations and Design Review. Journal of Coastal Research, 75(1), 715-719. http://dx.doi.org/10.2112/SI75-143.1

[20] Vijayaraghavan, R., Teepan Karti, S., \& Sathya, Y., (2018). Design of seawall. International journal of scientific development and research, 3(4), 283-292.

[21] Wang, L., Xie, Y., Wu, Y., Guo, Z., Cai, Y., Xu, Y., \& Zhu, X. (2012). Failure mechanism and conservation of the ancient seawall structure along Hangzhou Bay, China. Journal of Coastal Research, 28(6), 1393-1403.

http://dx.doi.org/10.2112/JCOASTRES-D-12-00036.1

[22] Williams, A. T., Giardino, A., \& Pranzini, E. (2016). Canons of coastal engineering in the United Kingdom: seawalls/groins, a century of change? Journal of Coastal Research, 32(5), 1196-1211. https://doi.org/10.2112/JCOASTRES-D-15-00213.1

[23] Yoo, C. I., Roh, S. H., \& Ryu, C. R. (2013). Estimation of Critical Limits by Marine work types for the Construction of Seawall at Sinseondae in Busan, Korea. Journal of Coastal Research, 65(sp1), 1075-1080.

http://dx.doi.org/10.2112/SI65-182.1 